Vol. 1, No 2, Seri C, Mei 2019, Hal 795-813
ISSN : 2656-3649 (Online)

http://jea.ppj.unp.ac.id/index.php/jea/issue/view/7

\title{
RELEVANSI INFORMASI LAPORAN KEUANGAN ACCRUAL BASIS: KEMAMPUAN RASIO KEUANGAN DALAM MEMPREDIKSI STATUS FINANCIAL DISTRESS PEMERINTAH DAERAH KABUPATEN DAN KOTA SE- INDONESIA PERIODE 2015-2017
}

\author{
Waninda ${ }^{1}$, Fefri Indra Arza ${ }^{2}$ \\ ${ }^{1)}$ Alumni Jurusan Akuntansi Fakultas Ekonomi Universitas Negeri Padang \\ 2)Jurusan Akuntansi Fakultas Ekonomi Universitas Negeri Padang \\ *Korespondensi: waninda159@gmail.com
}

\begin{abstract}
This study aims to predict the financial distress status of district and city governments in Indonesia. Research examines the relevance of financial statement information consisting of profitability ratio, liquidity ratio, performance ratio and capital stress ratio in predicting district and city government financial distress in Indonesia in 2015-2017. This study uses agency theory. The sampling method in this study used purposive sampling. This study consisted of 134 samples of districts / cities in Indonesia, the financial data used in the study were audited regional government financial reports, namely reports on audit results for 2015-2017. The type of data used is secondary data. The analysis used is binary logistic regression analysis. Based on the results of binary logistic regression analysis with a significance level of 5\%, that of the four types of ratios measured using fourteen measurements obtained results (1) Profitability ratio as measured by profit margin ratio affects financial distress with an $\beta$ coefficient of 51,548 and a significance value of $0,000<0.05$, (2) The performance ratio measured by operating revenue to total revenue has an effect on financial distress with an $\beta$ coefficient of -41.180 and $a$ significance value of 0.015>0.05, and a depreciation ratio influences financial distress with an $\beta$ coefficient of 40.004 and $a$ value significance of $0.004<0.05$
\end{abstract}

Keywords: Financial Distress, Profitability Ratio, Liquidity Ratio, Performance Ratio, and Capital Structure Ratio.

How to cite (APA $6^{\text {th }}$ style)

Waninda \& Arza, F. I. (2019). Relevansi informasi laporan keuangan accrual basis: kemampuan rasio keuangan dalam memprediksi status financial distress pemerintah daerah kabupaten dan kota se- indonesia periode 2015-2017. Jurnal Eksplorasi Akuntansi, 1(2), Seri C, 795-813.

\section{PENDAHULUAN}

Mahmudi (2003:77) menyatakan laporan keuangan sektor publik adalah bentuk pertanggungjawaban yang dilakukan oleh pemerintah kepada rakyat berkaitan dengan pengelolaan dana publik berupa pajak, retribusi atau transaksi lainnya. Menunjukkan pentingnya 
laporan keuangan bagi suatu entitas pemerintahan untuk mencatat dan mendokumentasikan setiap transaksi keuangan yang dilakukan. Tujuan umum pelaporan keuangan pemerintah dalam Peraturan Pemerintah No. 71 tahun 2010 adalah menyajikan informasi posisi keuangan, realisasi anggaran, arus kas, dan kinerja keuangan suatu entitas pelaporan bagi para pengguna dalam membuat dan mengevaluasi keputusan mengenai alokasi sumber daya. Tujuan utama pelaporan terkait informasi dengan pengambilan keputusan agar dapat bermanfaat bagi pengguna laporan keuangan. Pengambilan keputusan yang tepat akan memberikan implikasi positif dalam pelaksanaan penganggaran yang dilakukan oleh pemerintah terutama terkait dengan pembangunan kedepannya.

Laporan keuangan yang baik ditandai dengan laporan keuangan berkualitas. Membentuk laporan keuangan berkualitas harus didukung oleh adanya karakteristik kualitatif laporan keuangan. Menurut Peraturan Pemerintah No. 71 tentang Standar Akuntansi Pemerintah (SAP) karakteristik kualitatif laporan keuangan adalah ukuran-ukuran normatif yang penting untuk diwujudkan dalam informasi akuntansi sehingga memenuhi tujuan dari keberadaan laporan keuangan itu sendiri. Karakteristik kualitatif laporan keuangan pemerintah terdiri dari empat komponen, salah satunya relevan. Laporan keuangan dianggap bernilai relevan ketika informasi didalamnya mempengaruhi pengambilan keputusan mengevaluasi kejadian masa lalu atau saat ini dan memperkirakan masa depan serta membantu dalam mengkoreksinya. Laporan keuangan bernilai relevan dengan syarat yaitu nilai umpan balik (feedback value), manfaat prediktif (predictive value), tepat waktu (timelines) dan lengkap (completeness). Hal yang cukup menjadi perhatian adalah terkait manfaat prediktif. Manfaat prediktif membantu pengguna untuk memprediksi masa yang akan datang berdasarkan hasil masa lalu dan kejadian masa kini. Keberadaan nilai manfaat prediktif diharapkan bisa membantu memberikan sinyal atau peringatan terkait kemungkinan yang akan terjadi salah satunya terkait dalam memprediksi financial distress.

Jones dan Walker (2007) menjelaskan financial distress merupakan ketidakmampuan pemerintah untuk menyediakan pelayanan pada publik sesuai standar mutu pelayanan yang telah ditetapkan. Kondisi ini memberikan implikasi tidak terpenuhinya tanggung jawab pemerintah kepada masyarakat berupa tidak tersedianya dana untuk infrastruktur untuk pelayanan publik akibat kondisi keuangan dari pemerintah dalam keadaan kurang stabil walaupun dalam tingkatan yang lemah, sehingga menjadi sebuah sinyal buruknya kondisi keuangan pemerintah daerah saat ini. Kondisi keuangan pemerintah daerah seringkali menjadi permasalahan dan perhatian publik. Mengutip pernyataan Tubels (2015) permasalahan terjadi terkait alokasi dana tidak tepat, dimana dana yang ada tidak teralokasikan sebagaimana mestinya, sehingga meningkatkan probabilitas untuk mengalami kesulitan keuangan.

Pemberitaan dari Kontan. co.id menunjukkan keprihatinan para ekonom dikarenakan porsi belanja pemerintah hanya berfokus pada besarnya belanja pegawai yang membuat nilai belanja pemerintah belum produktif. Berdasarkan data deskripsi dan analisis Anggaran Pendapatan dan Belanja Daerah tahun 2014 yang diterbitkan oleh Kementerian Republik Indonesia (KEMENKEU-RI) menyebutkan bahwa rata-rata rasio belanja modal terhadap total belanja secara agregat provinsi, kabupaten dan kota sebesar 24,81\%. FITRA (Forum Indonesia untuk Transparansi) menjelaskan dalam Laporan Analisis Anggaran Daerah 2016 hasil penelitian di 70 kabupaten/kota bahwa rata-rata belanja modal terhadap total belanja sebesar $21 \%$ masih dibawah standar yang ditetapkan, bahkan pada observasi laporan keuangan periode 2015-2017 masih terdapat persentase belanja modal yang berkisar hanya 9-10\% saja. Data tersebut menandakan bahwa penyerapan belanja modal masih rendah, sehingga belanja modal yang 
rendah akan berdampak pada rendahnya pembangunan infrastruktur membuat pelayanaan tidak memadai sehingga pemerintah daerah berpotensi untuk mengalami financial distress.

Sartika (2016) menjelaskan bahwa penelitian mengenai prediksi financial distress dilakukan mengingat pentingnya peran pemerintah bagi masyarakat yang mempengaruhi prediksi financial distress, serta perbedaan hasil penelitian yang ditemukan oleh berbagai peneliti terdahulu. Prediksi tingkat financial distress sudah banyak dilakukan di Indonesia, akan tetapi lebih sering pada sektor swasta dalam perusahaan dan masih jarang pada sektor pemerintahan. Penelitian sebelumnya telah dilakukan beberapa pihak menguji nilai prediksi terkait dengan nilai relevan atas atribut dari laporan keuangan pemerintah, bermaksud untuk menghubungkan atribut laporan keuangan pemerintah dengan tujuan memprediksi kegagalan keuangan pemerintah. Sutaryo et al. (2012) menjabarkan prediksi kegagalan diukur dengan diantaranya bond rating dan yield obligasi pemerintah (Ingram et al., 1987; Plummer et al., 2007), interest cost (Reck et al., 2004) dan terkait service delivery (Jones dan Walker, 2007). Penelitian lainnya membuktikan bahwa atribut keuangan memiliki relevansi dalam memprediksi status financial distress (Cohen, 2008; Sutaryo, 2010; Cohen, 2012; Sutaryo et al, 2012 dan Wibowo dan Samekto, 2013). Penelitian secara empiris berhasil membuktikan bahwa atribut laporan keuangan pemerintah dapat digunakan untuk memprediksi kegagalan pemerintah daerah (financial distress) melalui analisis terkait rasio keuangan.

Dwijayanti (2010) menjabarkan bahwa analisis rasio keuangan merupakan cara yang paling sering digunakan untuk memprediksi financial distress. Rasio keuangan sebagai dasar perbandingan dalam menemukan kondisi serta tren yang sulit untuk dideteksi dalam mengungkapkan hubungan penting dengan mempelajari komponen yang membentuk rasio. Penelitian oleh berbagai pihak dilakukan untuk menemukan rasio keuangan dan model tepat yang bisa digunakan untuk memprediksi financial distress. Penelitian Yanti (2018) menggunakan short term solvency ratio, long term solvency ratio, budgetary solvency ratio, financial flexibility ratio, dan financial independence ratio dalam mengukur tingkat financial distress pada kab/kota Sumatera Barat. Sutaryo (2010) yang menemukan bahwa Return on Asset (ROA), Position Goverment Wealth (Posgw), Current Liquidity Goverment Wealth (CLGW), dan Long Term Debt to total Asset (LTDA) ratio berpengaruh signifikan terhadap financial distress. Penelitian berikutnya oleh Sutaryo, et al. (2012) membuktikan bahwa rasio keuangan atas laporan keuangan pemerintah daerah mempunyai kemampuan dalam memprediksi status financial distress pemerintah daerah, sehingga informasi dalam LKPD dianggap relevan untuk pengambilan keputusan bagi pemakainya dan membuktikan rasio keuangan dapat digunakan dalam memprediksi financial distress.

Sutaryo et al. (2012) yang menggunakan empat tipe rasio yang terdiri dari profitability ratio, liquidity ratio, performance ratio dan capital structure ratio dalam penelitiannya. Penelitian dengan empat tipe rasio diadaptasi dari sektor swasta dan jarang dilakukan serta sebelumnya menggunakan data laporan keuangan pemerintah kab/kota di Indonesia tahun 20052010 yang masih menggunakan sistem akuntansi cash modified basis. Sistem akuntansi yang digunakan saat ini adalah basis akrual dengan tujuh laporan keuangan pokok. Perkembangan terus terjadi tekait dengan sistem pencatatan akuntansi yang dilakukan pemerintah dalam bentuk reformasi sistem pencatatan. Berdasarkan Peraturan Pemerintah (PP) No. 24 tahun 2005 tentang SAP, bahwa akuntansi pemerintah menggunakan cash modified basis dan kemudian diperbaharui dengan PP No. 71 tahun 2010 yang menggunakan accrual basis. Keberadaan basis akrual dianggap membantu kinerja pemerintah lebih efektif dan efisien serta mendorong transparansi juga penerapan alokasi sumber daya yang lebih baik. Penjabaran diatas membuat peneliti ingin 
melihat kemampuan rasio keuangan yang sudah menggunakan acrual basis dalam memprediksi financial distress.

Penelitian ini mencoba untuk mengetahui apakah rasio keuangan berpengaruh dalam memprediksi financial distress pada pemerintah kab/kota se-Indonesia. Variabel yang digunakan dalam penelitian ini adalah profitability ratio, liquidity ratio, performance ratio dan capital structure ratio dalam memprediksi financial distress. Surepno (2013) menjelaskan profitability ratio merupakan rasio yang mengukur dan menggambarkan kemampuan entitas dalam hal menyediakan pengambilan keuangan menggunakan sumber daya yang digunakan, rasio ini sangat penting untuk menjadi tolak ukur bagaimana instansi membentuk efisiensi. Kasmir (2016:128) menjelaskan bahwa rasio likuiditas merupakan rasio yang alat ukur kemampuan instansi memenuhi kewajiban jatuh tempo, sehingga menjadi pertimbangan penting menilai kinerja instansi seberapa banyak aktiva lancar yang dimiliki perusahaan untuk menutupi kewajiban jangka pendek yang segera jatuh tempo. Sutaryo et al. (2012) menjelaskan performance ratio penting untuk melihat efisiensi yang merupakan pencapaian output yang maksimal dengan input tertentu atau penggunaan input yang terendah untuk mencapai output tertentu, sedangkan capital structure ratio merupakan proporsi antara jumlah utang dengan jumlah ekuitas atau aset entitas sehingga menjadi penting melihat relevansi elemen laporan keuangan yang dibentuk dalam rasio keuangan dalam memprediksi status financial distress pemerintah daerah.

Penelitian ini berbeda dengan penelitian sebelumnya dimana penelitian ini berfokus pada variabel keuangan yang menggunakan implementasi analisis rasio keuangan sektor swasta dengan mengacu pada penelitian Jones dan Walker (2007) dan Sutaryo (2012) dengan menambahkan beberapa variabel independen berupa rasio keuangan terkait arus kas dan aset tetap serta menggunakan data berupa laporan keuangan pemerintah daerah yang telah menerapkan basis akrual sejak tahun 2015, berbeda dengan sebelumnya yang masih menggunakan cash modified basis.

Tujuan dari penelitian untuk memprediksi status financial distress pemerintah kabupaten dan kota di Indonesia. Penelitian menguji relevansi dari informasi laporan keuangan yang terdiri dari profitability ratio, liquidity ratio, performance ratio dan capital strucuture ratio dalam memprediksi financial distress pemerintah kabupaten dan kota di Indonesia tahun 2015-2017

\section{KAJIAN TEORI}

\section{Teori (Agency Theory)}

Jensen dan Meckling (1976) menjelaskan teori keagenan (agency theory) sebagai hubungan antara principal (masyarakat dan DPRD) dan agent (pemerintah). Teori agensi memandang bahwa pemerintah daerah sebagai agents bagi masyarakat (principals) akan bertindak dengan penuh kesadaran bagi kepentingan mereka sendiri karena memiliki informasi lebih. Pemerintah sebagai agents dituntut untuk dapat transparan dalam menjalankan tugasnya, sehinga masyarakat dapat terus mengetahui kondisi keuangan dan mengawasi kinerja pemerintah daerah. Jensen dan Meckling (1976) menjabarkan keberadaan laporan keuangan terdiri dari angka-angka akuntansi diharapkan sebisa mungkin meminimalkan konflik diantara berbagai pihak yang berkepentingan.

Keberadaan laporan keuangan yang dilaporkan oleh agen yaitu pemerintah daerah sebagai bentuk pertanggungjawaban kinerjanya, principal dapat menilai, mengukur dan mengawasi sampai sejauh mana agen tersebut bekerja untuk meningkatkan kinerja dan melaksanakan tanggung jawabnya serta menilai kondisi keuangan pemerintah dearah. Pemerintah diharapkan untuk melakukan pengelolaan anggaran dengan dengan baik sehingga 
pengalokasian dana dapat tepat sasaran berdampak pada peningkatan kualitas pelayanan. Agent (pemerintah) diharapkan dapat bertindak bukan untuk kepentingan pribadi saja.

\section{Laporan Keuangan Pemerintah Daerah}

Menurut Bastian (2010) mendefinisikan bahwa definisi laporan keuangan adalah "hasil akhir proses akuntansi yang menyajikan informasi berguna untuk mengambil keputusan oleh berbagai pihak yang berkepentingan". Sesuai dengan Peraturan Pemerintah Nomor 71 Tahun 2010 tentang standar akuntansi pemerintahan (SAP) dinyatakan bahwa laporan keuangan adalah laporan terstruktur mengenai posisi keuangan dan transaksi yang dilakukan oleh suatu entitas pelaporan. Informasi dalam laporan keuangan penting untuk bernilai relevan sehingga dapat dimanfaatkan dalam pengambilan keputusan penggunanya evaluasi maupun untuk masa depan.

Basis pencatatan akuntansi dalam penyusunan laporan keuangan telah mengalami perubahan dari basis kas menuju akrual menjadi basis kas. Menurut Erlina et al. (2015:11) fokus sistem akuntansi akrual fokus pada pengukuran sumber daya ekonomis dan perubahan daya pada suatu entitas. PSAP No. 1 Paragraf 8 menjabarkan definisi akuntansi berbasis akrual adalah "basis akuntansi yang mengakui pengaruh transaksi dan peristiwa lainnya pada saat transakasi dan peristiwa itu terjadi, tanpa memperhatikan saat kas atau setara kas diterima atau dibayar".

\section{Financial Distress}

Jones dan Walker (2007) menjelaskan bahwa financial distress merupakan ketidakmampuan pemerintah untuk menyediakan pelayanan pada publik sesuai standar mutu pelayanan yang telah ditetapkan. Ketidakmampuan pemerintah ini karena pemerintah tidak mempunyai ketersediaan dana untuk diinvestasikan pada infrastruktur yang digunakan dalam penyediaan pelayanan pada publik tersebut. Menurut Cohen (2012) aspek penting dari penelitian financial distress adalah pertimbangan terkait dengan membedakan pemerintah daerah yang mengalami masalah keuangan dan mana yang sehat. Financial distress menggambarkan kondisi keuangan pemerintah dalam kondisi yang kurang baik.

Financial distress pemerintah daerah pada penelitian ini mengikuti definisi Jones dan Walker (2007) Kemampuan pelayanan pemerintah diukur menggunakan belanja modal mengikuti Peraturan Presiden Republik Indonesia No. 5 Tahun 2010 tentang Rencana Pembangunan Jangka Menengah Nasional (RPJMN) Tahun 2010-2014 dan Peraturan Presiden Republik Indonesia No. 2 Tahun 2015 tentang Rencana Pembangunan Jangka Menengah Nasional (RPJMN) Tahun 2015-2019 dengan porsi belanja modal 30\%, dibawah jumlah tersebut diindikasikan mengalami financial distress.

\section{Rasio Keuangan}

Analisis rasio (ratio analysis) merupakan salah satu alat analisis keuangan yang paling populer dan banyak digunakan. Rasio menggambarkan hubungan matematis antara. Subramanyam dan Wild (2010:42) menyebutkan analisis rasio dapat mengungkapkan hubungan penting dan menjadi dasar perbandingan dalam menemukan kondisi dan tren yang sulit untuk dideteksi dengan mempelajari masing- masing komponen yang membentuk rasio. Rasio keuangan terdiri dari profitability ratio, liquidity ratio, performance ratio dan capital structure ratio yang diukur dengan 14 pengukuran. 


\section{Profitability ratio dan Financial Distress}

Maulida et al. (2018) rasio profitabilitas adalah rasio yang digunakan untuk mengukur kemampuan suatu perusahaan dalam mendapatkan laba. Rasio ini karena hal ini berkaitan erat dengan kelangsungan hidup entitas. Penyesuaian elemen rasio sektor pemerintah dilakukan dikarenakan organisasi pemerintah yang non profit oriented, rasio profitabilitas disesuaikan (adjust) melalui penggantian laba (rugi) dengan surplus (defisit) atas anggaran pemerintah. Surplus (defisit) yang tinggi mengindikasikan bahwa pemerintah kurang baik dalam pelaksanaan anggarannya. Cohen (2008) menyatakan bahwa diperlukan surplus dalam jumlah yang wajar agar pemerintah daerah dapat memenuhi investasi jangka panjang, serta dengan rasio profitabilitas dapat menjadi wahana membentuk efisiensi sumber daya dan meningkatkan pertumbuhan. Nilai positif rasio profitabilitas yang kecil dianggap lebih menguntungkan, sedangkan nilai negatif besar menjadi prospek keuangan yang juga tidak menguntungkan. Sejalan dengan penjelasan diatas, Sutaryo (2010) menjabarkan bahwa berbeda dengan sektor swasta, surplus belum tentu menandakan pemerintah daerah mempunyai dana yang cukup untuk membiayai pembangunan periode berikutnya. Permasalahan muncul ketika surplus yang ada harus dikembalikan ke kas negara dan pengajuan anggaran periode berikutnya hanya diperbolehkan sesuai dengan realisasi anggaran tahun sebelumnya, sehingga memunculkan probabilitas financial distress kedepannya.

Profitability ratio dapat diukur dengan ROA, ROE, dan profit margin ratio, berbagai penelitian membuktikan terkait nilai relevan dari profitability ratio dalam membuktikan status financial distress pemerintah daerah. Cohen (2008) menemukan bahwa tiga rasio diatas mampu dalam menjelaskan kinerja keuangan pemerintah daerah Yunani, begitu juga Sutaryo et al. (2012) menggunakan rasio tersebut dalam memprediksi status financial distress. Jones dan Walker (2007) menggunakan ROA sebagai explanatory local government distress di Australia. Nilai profit margin ratio semakin besar menandakan besarnya surplus dari setiap pendapatan pemerintah daerah yang dihasilkan sehingga berpengaruh terhadap kondisi financial distress pemerintah daerah. Penjelasan terkait ROA dikutip dari Wibowo dan Sumekto (2013) menjelaskan bahwa pemerintah daerah yang memiliki nilai rasio ROA yang tinggi diindikasikan lebih cenderung untuk mengalami financial distress dikarenakan besarnya nilai surplus yang tinggi dibandingkan jumlah aset pemerintah daerah, sejalan dengan ROA dan PM untuk nilai ROE yang semakin meningkat menandakan bahwa semakin besar pengaruhnya terkait dengan financial distress pemerintah daerah karena besarnya nilai surplus yang dihasilkan dari keberadaan modal/ekuitas yang dimiliki pemerintah daerah. Berdasarkan pernyataan tersebut peneliti merumuskan hipotesis sebagai berikut :

Profitability ratio yang dimaksud meliputi:

H1a: Profit margin ratio mempunyai kemampuan dalam memprediksi financial distress pemerintah daerah.

H1b: Return on Asset (ROA) mempunyai kemampuan dalam memprediksi financial distress pemerintah daerah.

H1c: Return on Equity (ROE) mempunyai kemampuan dalam memprediksi financial distress pemerintah daerah.

\section{Liquidty Ratio dan Financial Distress}

Maulida, Indira et al. (2018) menjelaskan rasio likuiditas adalah rasio yang digunakan untuk mengukur seberapa likuidnya suatu perusahaan dengan membandingkan komponen yang ada di 
neraca, yaitu total aktiva lancar dengan total passiva lancar (utang jangka pendek). Ritongga et al. (2012) menyebutkan bahwa liquidity ratio menjadi indikator kinerja keuangan penting dalam memprediksi status financial distress dikarenakan semakin tinggi nilai rasio semakin tinggi tingkat likuiditas suatu pemerintah daerah. Likuiditas tinggi menandakan bahwa instansi pemerintah mampu daerah untuk membayar kewajiban jangka pendeknya akan semakin baik atau semakin lancar. Liquidity ratio dapat diukur dengan current ratio dan working capital ratio. Temuan dalam penelitan sebelumnya mendukung bahwa liquidity ratio memiliki nilai relevan dalam memprediksi status financial distress.

Cohen (2008) menemukan bahwa dua rasio diatas mampu dalam menjelaskan kinerja keuangan pemerintah daerah Yunani, begitu juga Sutaryo et al. (2012) menggunakan rasio tersebut dalam memprediksi status financial distress. Cohen (2008) menyatakan bahwa rasio CR menjadi indikator penting dalam melihat prospek keuangan masa mendatang, nilai CR rendah akan berdampak pada arus kas yang bermasalah sehingga akan membutuhkan pinjaman jangka pendek lebih besar untuk menutupi berbagai biaya yang ada, sejalan dengan pernyatan diatas Kholidah et al. (2016) menjelaskan bahwa current ratio dapat memprediksi financial distress berarti semakin tinggi nilai current ratio, semakin rendah risiko perusahaan mengalami financial distress. Current ratio yang tinggi menunjukkan kemampuan perusahaaan dalam membayar kewajiban jangka pendek atau utang yang segera jatuh tempo semakin baik. Pengukuran lain dari liquidity ratio adalah dengan working capital ratio yang menunjukkan bahwa semakin tinggi nilai rasio ini, maka semakin baik posisi keuangan pemerintah daerah dikarenakan jumlah aset lancar lebih besar dibandingkan dengan kewajiban sehingga keberadaan aset mampu untuk menutupi utang jangka pendeknya dan dibandingkan dengan aset keseluruhan yang akan berdampak pada berkurangnya kemungkinan financial distress, sehingga muncul hipotesis:

Liquidity ratio yang dimaksud meliputi:

H2a: Current Ratio (CR) mempunyai kemampuan dalam memprediksi financial distress pemerintah daerah.

H2b: Working Capital to Total Asset Ratio (WCTA) mempunyai kemampuan dalam memprediksi financial distress pemerintah daerah.

\section{Performance Ratio dan Financial Distress}

Sutaryo et al. (2012) menjelaskan kinerja pemerintah dapat diukur dengan efisiensi yang merupakan pencapaian output yang maksimal dengan input tertentu, atau penggunaan input yang terendah untuk mencapai output tertentu, sehingga efisiensi sangat berkaitan dengan input dan ouput. Rasio kinerja melihat seberapa efisien penggunaan pendapatan atau dana yang dimiliki oleh pemerintah daerah untuk mendukung pelaksanaan kinerja. Penggunaan dana dan pemanfaatan pendapatan daerah yang semakin efisien oleh pemerintah daerah maka hal tersebut akan berdampak kepada keuangan pemerintah daerah, dimana pemerintah daerah terhindar dari kondisi kesulitan keuangan atau financial distress..

Pengukuran performance ratio memiliki masing-masing hubungan dengan financial distress. Pengukuran menggunakan rasio OROE Sutaryo, et al. (2012) menjelaskan bahwa nilai rasio rendah mengindikasikan bahwa pemerintah mempunyai pengeluaran yang tinggi dan mengindikasikan bahwa pemerintah daerah dalam kondisi yang tidak efisien serta mempunyai probabilitas yang tinggi untuk berada dalam status financial distress. Sutaryo, et al. (2012) menjelaskan bahwa rasio ORTR yang tinggi mengindikasikan bahwa pemerintah daerah mampu menciptakan pendapatan operasional (PAD) yang tinggi sehingga mampu memberikan 
kontribusi yang tinggi terhadap total pendapatan daerah. Kondisi ini dapat dinyatakan bahwa pemerintah daerah berada dalam kondisi yang efisien dan dapat berpengaruh terhadap kondisi keuangan pemerintah daerah.

Pengukuran Operating expense/ own revenues (OE/R) dijelaskan oleh Cohen (2008) bahwa semakin tinggi rasio OE/R maka semakin bergantung suatu pemerintahan agar memiliki kondisi keuangan yang sehat, hal tersebut dikarenakan pendapatan asli daerah tidak mampu dalam membiayai beban operasional pemerintah sehingga berdampak pada ketergantungan terhadap transfer dari pemerintah pusat. Ketergantungan meningkatkan resiko keuangan yang dihadapi sehingga tidak terkontrol, sehingga mengarah pada kondisi financial distress. Rasio depreciation menghasilkan nilai besar dapat berpengaruh kepada beban operasional pemerintah sehingga dana yang dialokasikan untuk beban menjadi lebih besar serta jumlah depresiasi yang tinggi akan berdampak terhadap nilai dan masa manfaat dari aset, sehingga pemerintah daerah nantinya akan membutuhkan sejumlah penggantian barang modal dari aset akan memunculkan kebutuhan pembiayaan baru menyebabkan dana dibutuhakan semakin besar jumlahnya yang membuat kemungkinan terjadi financial distress semakin meningkat. Pengukuran terakhir berkaitan dengan arus kas yaitu rasio cash flow operation to current liablities, ditemukan bahwa hasil perhitungan rasio rendah dibawah 1 diartikan pemerintah daerah tidak mampu melunasi kewajiban lancarnya dengan arus kas operasi saja dan sebaliknya. Berdasarkan penjelasan diatas, peneliti merumuskan hipotesis sebagai berikut:

Performance ratio yang dimaksud meliputi:

H3a: Operating Revenue to Operating Expense Ratio (OROE) mempunyai kemampuan dalam memprediksi financial distress pemerintah daerah.

H3b: Operating Revenue to Total Revenue Ratio (ORTR) mempunyai kemampuan dalam memprediksi financial distress pemerintah daerah.

H3c: Operating Revenue to Total Operating expensel own revenues $(O E / R)$ mempunyai kemampuan dalam memprediksi financial distress pemerintah daerah.

H3d: Depreciation mempunyai kemampuan dalam memprediksi financial distress pemerintah daerah.

H3e: Cash flow operation to current liablities mempunyai kemampuan dalam memprediksi financial distress pemerintah daerah.

\section{Capital Structure Ratio dan Financial Distress}

Turaboglu et al (2017) menjabarkan bahwa keputusan terkait struktur modal adalah hal penting dalam menyingkirkan kesulitan keuangan. Ketika perusahaan berhutang berlebihan dari keputusan struktur modal akan menyebabkan keadaan memburuk dan pengembalian dan pemenuhan kewajiban tidak dapat dilakukan. Cohen (2008) menjelaskan bahwa capital structure ratio dapat menjadi gambaran bagaimana pemerintah daerah dalam membiayai aset yang dimilikinya dalam waktu jangka panjang, nilai rasio yang tinggi dapat menimbulkan keraguan terkait kemampuan pemerintah daerah membayar seluruh utang disertakan dengan suku bunganya.

Capital Structure Ratio dapat diukur dengan debt equity ratio, long term liabilities to total asset ratio, debt to total asset ratio, debt to revenue. Cohen (2008) menjelaskan bahwa nilai DER satu atau kurang adalah indikator yang menguntungkan. Nilai rasio DER yang tinggi menandakan semakin besar leverage kota dan karenanya semakin besar penggunaan dana utang untuk menambah dana ekuitas internal. Rasio kedua berkaitan dengan perbedaan antara 
kewajiban jangka pendek dan jangka panjang. Tingkat leverage yang dibenarkan sangat terkait dengan aktivitas penghasil uang suatu kota. Tingkat leverage yang tinggi menimbulkan keraguan dalam kaitannya dengan kemampuannya untuk membayar hutang dengan suku bunga yang wajar serta mempengaruhi solvabilitasnya serta dijelaskan bahwa nilai sangat rendah atau sangat tinggi dari rasio ini yang mengindikasikan kondisi keuangan yang tidak sehat.

Sutaryo et al. (2012) menemukan bahwa long term liabilities to total asset ratio memiliki kemampuan dalam memprediksi financial distress karena dapat digunakan sebagai ukuran perbandingan total aktiva perusahaan dibiayai oleh hutang jangka panjang, sehingga semakin tinggi nilai rasio ini menandakan semakin besar kemungkinan financial distress pemerintah daerah. Perbandingan rasio debt to total asset berdasarkan penjelasan Sutaryo et al. (2012) dapat digunakan dalam memprediksi financial distress, bahwa semakin besar hasil rasio maka semakin besar jumlah aset perusahaan yang dibiayai oleh hutanh. Mei- linda (2012) dalam Restianti dan Agustina (2018) menjelaskan bahwa rasio utang terhadap aset dapat menjadi sinyal perusahaan, kerena semakin besar kegiatan perusahaan yang dibiayai utang, semakin besar kondisi kesulitan keuangan, karena jumlah kewajiban yang besar untuk membayar hutang. Sutaryo (2012) menjelaskan tingginya rasio debt to revenue karena tindakan untuk melakukan pengambilan pinjaman daerah tidak sejalan dengan kemampuan untuk membayar kembali pinjaman, maka hal tersebut akan menyulitkan dan membuat pemerintah daerah tersebut terjebak dalam utang serta jumlah tanggungan utang semakin besar sehingga akan menimbulkan kondisi financial distress. Keputusan struktur modal menjadi penting untuk melihat seberapa besar pengaruhnya dalam mendukung keuangan pemerintah daerah sehingga terbentuk hipotesis berikut:

Capital Structure Ratio yang dimaksud meliputi:

H4a: Debt to Equity Ratio (DER) mempunyai kemampuan dalam memprediksi financial distress pemerintah daerah.

H4b: Long term liabilities to total asset ratio mempunyai kemampuan dalam memprediksi financial distress pemerintah daerah.

H4c: Debt to total asset ratio mempunyai kemampuan dalam memprediksi financial distress pemerintah daerah.

H4d: Debt to revenue ratio mempunyai kemampuan dalam memprediksi financial distress pemerintah daerah.

\section{METODE PENELITIAN}

Jenis penelitian yang akan diteliti dalam penelitian ini adalah jenis penelitian kuantitatif. Curwin and Slater (2008:7) menjelaskan bahwa pendekatan kuantitatif menggunakan angka untuk membantu menggambarkan dan memecahkan masalah yang memiliki konteks dengan makna setiap angka dan kepentingan relatif dari informasi. Populasi dalam penelitian ini adalah semua pemerintah kabupaten kota di Indonesia tahun 2015-2017. Berdasarkan data yang diperoleh, terdapat 518 kabupaten kota di Indonesia.

Pemilihan sampel dalam penelitian ini menggunakan teknik purposive sampling, yaitu teknik pengambilan sampel dengan kriteria tertentu. Jumlah sampel dalam penelitian ini sebanyak 67 pemerintah daerah. Teknik Analisis Data Analisis data dalam penelitian ini menggunakan model regresi logistik biner. Menurut Hosmer dan Lemeshow (2000) regresi logistik biner merupakan suatu metode analisis data yang digunakan untuk mencari hubungan antara variabel respon (y) yang bersifat biner atau dikotomi dengan variabel prediktor (x) yang bersifat polikotomi. Keluaran dari variabel respon y terdiri dari 2 kategori yang dinotasikan 
dengan $\mathrm{y}=1$ (non financial distress) dan $\mathrm{y}=0$ (financial distress). Kategori tersebut didasarkan pada rasio belanja modalnya, jika kurang dari 30\% maka termasuk dalam kategori financial distress namun jika tercapai 30\% maka dikategorikan non financial distress (Peraturan Presiden No. 5/2010 tentang Rencana Pembangunan Jangka Menengah Nasional Tahun 20102014 dan Peraturan Presiden No. 2/2015 tentang Rencana Pembangunan Jangka Menengah Nasional Tahun 2015-2019).

Model persamaan regresi logistik biner dalam penelitian ini adalah sebagai berikut ini:

$$
\begin{gathered}
\operatorname{Ln} \frac{p}{p-1}=\beta 0+\beta 1(\mathrm{PM})+\beta 2(\mathrm{ROA})+\beta 3(\mathrm{ROE})+\beta 4(\mathrm{CR})+\beta 5(\mathrm{WCTA})+\beta 6(\mathrm{OROE})+\beta 7(\mathrm{ORTR})+\beta 8(\mathrm{OE} / \mathrm{R}) \\
+\beta 9(\mathrm{DEPR})+\beta 10(\mathrm{CFOCL})+\beta 11(\mathrm{DER})+\beta 12(\mathrm{LTAR})+\beta 13(\mathrm{DAR})+\beta 14(\mathrm{DR})
\end{gathered}
$$

\section{Definisi Operasional dan Pengukuran Variabel Penelitian Financial Distress}

Financial distress pemerintah daerah diartikan sebagai ketidakmampuan pemerintah daerah dalam menberikan pelayanan sesuai standar kepda masyarakat dikarenakan masalah kurangnya dana infrastruktur. Kondisi tersebut menyebabkan pemerintah daerah akan mengalami kondisi kesulitan keuangan sehingga sulit untuk memenuhi kewajibannya dalam memberikan pelayanan sesuai standar kepada masyarakat. Prediksi terkait financial distress diperlukan oleh pemerintah daerah dan dilakukan sejak awal agar dapat dilakukan tindakan-tindakan perbaikan untuk kondisi lebih baik, sehingga harapan masyarakat dapat terpenuhi. Diukur dengan:

$$
\text { Proporsi Belanja Modal }=\frac{\text { Realisasi Belanja Modal }}{\text { Total Belanja Daerah }}
$$

\section{Profitabliity Ratio}

Profitabliity Ratio atau rasio profitabilitas merupakan rasio yang menggambarkan kemampuan entitas dalam menyediakan pengembalian keuangan dengan sumber daya yang digunakan. mengukur kemampuan suatu bisnis untuk mendapatkan keuntungan bagi pemiliknya, menunjukkan seberapa baik perusahaan menggunakan asetnya untuk menghasilkan nilai bagi kepentingan instansi pemerintahan dan pemenuhan pelayanan kepada masyarakat.

$$
\text { Profit Margin Ratio }=\frac{\text { Net Income (Surplus) }}{\text { Pendapatan }} \quad \text { ROA }=\frac{\text { Net Income (Surplus) }}{\text { Total Aset }} \quad \text { ROE }=\frac{\text { Net Income (Surplus) }}{\text { Ekuitas }}
$$

\section{Liquidity Ratio}

Liquidity Ratio atau rasio likuiditas merupakan rasio keuangan yang digunakan sebagai salah satu bentuk analisis untuk melihat kemampuan suatu instansi untuk mengkonversi asetnya menjadi uang tunai dan melunasi kewajibannya tanpa kesulitan yang signifikan yang nantinya akan membantu menjelaskan posisi keuangan suatu bisnis. Keberadaan rasio ini sangat bermanfaat bagi berbagai pihak seperti kreditur dan pemerintah itu sendiri. Diukur menggunakan:

$$
\text { Current Ratio }=\frac{\text { Aset Lancar }}{\text { Hutang Lancar }} \quad \text { WCTA }=\frac{\text { Aset Lancar }- \text { Kewajiban Lancar }}{\text { Total Aset }}
$$

\section{Performance Ratio}

Performance Ratio atau rasio kinerja memberikan perbandingan untuk melihat efisiensi mengkomunikasikan kinerja keuangan suatu instansi dapat digunakan dalam mengukur seberapa 
efisien Perusahaan dalam menggunakan asetnya untuk memenuhi kebutuhan perusahaan tersebut. Diukur menggunakan:

$$
\begin{gathered}
\text { OROE }=\frac{\text { operating Revenue }}{\text { Operating Expenses }} \quad \text { Rasio } \frac{O E}{R}=\frac{\text { Operating Expense }}{\text { Own Revenues }} \quad \text { Depr }=\frac{\text { Depreciation Expense }}{\text { Cost of Depreciation Fixed Assets }} \\
\text { ORTR }=\frac{\text { Operating Revenue }}{\text { Total Revenue }} \text { CFO to Current Liability }=\frac{\text { Arus Kas Operasi }}{\text { Kewajiban Lancar }}
\end{gathered}
$$

\section{Capital Structure Ratio}

Rasio ini merupakan proporsi antara jumlah utang dengan jumlah ekuitas atau aset entitas. Rasio yang tinggi memberi gambaran bahwa entitas mempunyai kewajiban untuk memenuhi utang jangka panjang dalam jumlah yang tinggi dengan menggunakan ekuitas atau aktiva tetap yang dimiliki. Jumlah utang jangka panjang yang tinggi dapat berpengaruh terhadap kondisi keuangan entitas dalam jangka panjang sehingga dapat berpengaruh terhadap financial distress (Almilia, 2006). Diukur dengan menggunakan:

$$
\begin{gathered}
\text { Debt to Equity Ratio }=\frac{\text { Total Hutang }}{\text { Ekuitas }} \text { Longterm debt to Total Asset Ratio }=\frac{\text { Long term debt }}{\text { Total Aset }} \\
\text { Debt to Total Asset Ratio }=\frac{\text { Total debt }}{\text { Total Aset }} \text { Debt to Revenue }=\frac{\text { Total debt }}{\text { Total Revenue }}
\end{gathered}
$$

\section{PEMBAHASAN}

Hasil Penelitian

Deskripsi Data Penelitian ini dilakukan pada pemerintah daerah kabupaten dan kota yang ada di Indonesia. Penelitian ini dilakukan dengan mengolah data laporan keuangan dari tahun 2015 sampai dengan tahun 2017 menggunakan data yang diperoleh dari Badan Pemeriksa Keuangan Republik Indonesia (BPK RI) Perwakilan Provinsi Sumatera Barat untuk periode 2015-2017. Analisis Statistik Deskriptif Statistik deskriptif digunakan untuk mengetahui data yang diteliti dengan melihat dari nilai minimum, maksimum, rata-rata (mean) dan standar deviasi agar data lebih jelas dan mudah dipahami.

Pembahasan Berdasarkan analisis data yang diperoleh, koefisien determinasi, nilai Nagelkerke R Square adalah 0,707. Hal ini menunjukkan bahwa rasio keuangan mampu menjelaskan pengaruh terhadap financial distress dalam model yang digunakan oleh penelitian sebesar 70,7\%. Sedangkan 29,3\% lainnya dijelaskan oleh faktor luar seperti good governance, kondisi wilayah, dan pemekaran wilayah. Dari pengujian parameter regresi logistik dapat diketahui besaran dan arah pengaruh masing-masing variabel independen terhadap variabel dependen.

\section{Profitability Ratio Dalam Memprediksi Financial Distress}

Profitability ratio diukur dengan profit margin ratio memiliki nilai signifikan sebesar 0,000 dan koefisien 51.548. Nilai signifikansi yang dihasilkan tersebut lebih kecil daripada nilai alpha $(0,05)$ atau $(<0,05)$, sehingga disimpulkan berpengaruh signifikan terhadap financial distress sejalan dengan penelitian terdahulu dari Sutaryo et al. (2012) yang memperoleh hasil bahwa kemampuan pemerintah daerah dalam pemanfaatan pendapatan daerahnya dalam membiayai kegiatan dan membentuk efektivitas kinerja berpengaruh signifikan terhadap financial distress.

Hal ini sejalan pernyataan Cohen (2008) yang menjelaskan bahwa keberadaan surplus wajar yang dihasilkan diharapkan dapat dimanfaatkan dengan baik untuk kegiatan investasi 
modal jangka panjang serta dapat digunakan untuk pembiayaan kegiatan pemerintahan kedepannya, namun tidak sejalan dengan hasil temuan penelitiannya yang menemukan profit margin ratio tidak berpengaruh terhadap financial distress. Pendapatan yang ada digunakan sebagai bentuk investasi untuk memaksimalkan pendapatan dikemudian hari, bentuk investasi yang dilakukan pemerintah untuk meningkatkan pendapatan dapat dioperasikan dalam pola intensifikasi dan ekstensifikiasi pendapatan asli daerah serta investasi dalam bisnis di sektor hulu dan hilir dalam struktur perekonomian lokal (Halim, 2008) .

Ukuran kedua menggunakan Return on Asset (ROA) mempunyai nilai signifikansi 0,695 dan koefisien -111.564. Nilai signifikansi yang lebih besar dari 5\% menunjukkan bahwa return on asset tidak berpengaruh signifikan terhadap financial distress. Ketidaksesuaian hasil yang didapatkan dikarenakan surplus pemda tidak berasal dari efisiensi, akan tetapi surplus yang ada tersebut berasal dari alokasi anggaran kegiatan yang tidak direalisasikan (Wibowo dan Sumekto, 2013) Keberadaan dari aset yang pemerintah daerah miliki tentunya dapat dimanfaatkan dan dikelola dengan sebaik mungkin, namun keberadaan aset belum mampu dalam membentuk efisiensi dalam menghasilkan surplus wajar bagi pemerintah daerah.

Pernyataan lain dari Wibowo Sumekto (2013) juga menjelaskan bahwa ROA tidak mampu atau relevan dalam memprediksi financial distress dikareanakan surplus atau defisit yang dimiliki pemda dimasukkan ke dalam pos SILPA (Sisa Lebih Penggunaan Anggaran) atau defisit akan dimasukkan kedalam pos SIKPA (Sisa Kurang Penggunaan Anggaran) yang didasarkan pada UU Republik Indonesia No 32 Tahun 2004. Hasil penelitian ini juga sejalan dengan Cohen (2008) yang meneliti tentang faktor-faktor yang mempengaruhi kinerja keuangan pemerintah daerah yang ada di Yunani yang menemukan bahwa return on asset kurang berpengaruh pada kinerja pemerintah di Kota Greek, Yunani dan tidak mengindikasikan financial distress karena hanya dipengaruhi oleh jumlah penduduk dan pendapatan perkapita.

Pengukuran ketiga menggunakan Return on Equity (ROE) memiliki nilai signifikansi 0,807 dan koefisien 67.346. Nilai signifikansi yang lebih besar dari 5\% menunjukkan bahwa return on equity tidak berpengaruh signifikan terhadap financial distress. Serupa dengan return on asset yang dianggap tidak berpengaruh signifikan tidak sejalan dengan Sutaryo et al. (2012) yang menyatakan return on equity berpengaruh signifikan terhadap financial distress. Tidak berpengaruhnya ROE dalam memprediksi financial distress dikarenakan keberadaan ekuitas yang dimiliki oleh pemerintah daerah dianggap belum mampu untuk membentuk efisiensi sehingga surplus yang ada belum berasal dari pengelolaan ekuitas yang baik, serta pernyataan bahwa Wibowo dan Sumekto (2013) bahwa surplus yang ada berasal dari alokasi anggaran yang tidak direalisasikan. Temuan ini juga sejalan dengan Cohen (2008) yang menemukan bahwa return on equity kurang berpengaruh pada kinerja pemerintah di Kota Greek, Yunani dan tidak mengindikasikan financial distress.

\section{Liquidity Ratio dalam Memprediksi Financial Distress}

Liquidity ratio diukur menggunakan Current Ratio $(C R)$ mempunyai hasil pengujian hipotesis keempat memiliki nilai signifikansi 0,636 dan koefisien 0,009. Nilai signifikansi yang lebih besar dari 5\% menunjukkan bahwa current ratio tidak berpengaruh signifikan terhadap financial distress, sehingga terlihat bahwa kemampuan pemerintah daerah dalam memenuhi kewajiban jangka pendeknya dianggap tidak memberikan jaminan akan terbebasnya pemerintah daerah tersebut dari potensi financial distress. Hasil dari penelitian ini tidak sejalan dengan Sutaryo et al. (2012) yang menyatakan bahwa current ratio dianggap relevan dalam memprediksi status 
financial distress pemerintah daerah, serta tidak sejalan dengan Plammer et al. (2007) berpengaruh terhadap risiko kegagalan pemerintah.

Akan tetapi hasil penelitan yang didapatkan sejalan dengan penelitian yang dilakukan oleh Jones dan Walker (2008) yang memperoleh hasil bahwa rasio likuiditas tidak berpengaruh signifikan terhadap financial distress pemerintah lokal di negara bagian Australia. Likuiditas tinggi tidak memberi jaminan lepas financial distress dikarenakan seringkali instansi yang liquid mangalami financial distress (Tukan, 2017). Penelitian ini juga sejalan dengan penelitian Cohen (2008) yang mengatakan bahwa rasio hutang termasuk current ratio tidak atau kurang berpengaruh pada kinerja pemerintah di Kota Greek, Yunani, serta penelitian ini sejalan dengan Yanti (2018) yang menemukan bahwa short term solvency ratio yang merupakan istilah sama untuk current ratio yang menyatakan bahwa short term solvency ratio tidak berpengaruh signifikan terhadap financial distress pada kabupaten dan kota di Sumatera Barat tahun 20122017.

Ukuran kedua menggunakan Working Capital to total asset Ratio (WCTA) hasil pengujian dari hipotesis kelima memiliki nilai signifikansi 0,148 dan koefisien 5,915. Nilai signifikansi yang lebih besar dari 5\% menunjukkan bahwa working capital ratio berpengaruh tidak signifikan terhadap financial distress. Likuiditas tinggi tidak memberi jaminan lepas financial distress dikarenakan seringkali instansi yang liquid mangalami financial distress (Tukan, 2017). Hasil yang didapatkan dari penelitan ini sejalan dengan Sutaryo et al. (2012) yang menemukan bahwa working capital ratio tidak relevan dalam memprediksi status financial distress pemerintah daerah kabupaten kota di Indonesia. Penelitian ini juga sejalan dengan penelitian Cohen (2008) yang mengatakan bahwa rasio hutang termasuk current ratio tidak atau kurang berpengaruh pada kinerja pemerintah di Kota Greek, Yunani. Hasil penelitian yang dilakukan oleh Saifi dan helena (2018) menunjukkan bahwa semakin besar anggota dewan direksi semakin besar kemungkinan perusahaan mengalami kesulitan keuangan pada perusahaan. Turunnya kemampuan perusahaan dalam mengelola perusahaan disebabkan karena disibukkan oleh masalah koordinasi sehingga dewan direksi tidak berfungsi secara optimal dalam mengelola perusahaan. Perusahaan yang mengalami tekanan keuangan yang besar biasanya membutuhkan pertimbangan tentang keadaan keuangan perusahaan dari para direktur.

\section{Performance Ratio Dalam Memprediksi Financial Distress}

Performance ratio Operating Revenue to Operating Expense Ratio (OROE) mempunyai hasil pengujian hipotesis keempat memiliki nilai signifikansi 0,365 dan koefisien 3,184. Nilai signifikansi yang lebih besar dari 5\% menunjukkan bahwa operating revenue to operating expense ratio tidak berpengaruh signifikan terhadap financial distress. Hasil ini tidak sejalan dengan hasil temuan Sutaryo et al. (2012) yang menyatakan bahwa rasio ini dianggap mampu dan relevan dalam memprediksi status financial distress.

Ketidakmampuan rasio OROE dalam memprediksi status financial distress dikarenakan dalam laporan keuangan pemerintah daerah yang dijadikan sampel, terlihat bahwa kemampuan pemerintah daerah dalam memenuhi kebutuhan beban operasi tidak memberikan jaminan akan terbebasnya pemerintah daerah tersebut dari potensi financial distress, terlebih jumlah pendapatan operasi yaitu pendapatan asli daerah yang berasal dari kegiatan perpajakan dan retribusi jumlahnya kecil jika dibandingkan dengan beban operasi yang harus ditanggung.

Hipotesis ketujuh dalam penelitian ini yaitu $\left(\mathrm{H}_{3 \mathrm{~b}}\right.$ Operating Revenue to Total Revenue Ratio (ORTR) mempunyai hasil pengujian hipotesis keempat memiliki nilai signifikansi 0,015 dan koefisien $-41,180$. Nilai signifikansi yang lebih kecil dari 5\% menunjukkan bahwa operating 
revenue to total revenue ratio mempunyai nilai relevansi yang berpengaruh signifikan terhadap financial distress, sehingga penelitian ini berhasil mendukung hipotesis keempat yang menyatakan bahwa operating revenue to total revenue ratio berpengaruh signifikan terhadap financial distress. Hasil ini sejalan dengan hasil temuan Sutaryo et al. (2012) yang menyatakan bahwa rasio ini dianggap mampu dan relelvan dalam memprediksi status financial distress.

Kemampuan rasio ORTR dalam memprediksi status financial distress dikarenakan bahwa dalam laporan keuangan pemerintah daerah yang dijadikan sampel, terlihat bahwa kemampuan pemerintah daerah bahwa komposisi atau perbandingan antara pendapatan operasi yaitu Pendapatan Asli Daerah (PAD) dengan total revenue dapat memberikan indikasi terkait potensi financial distress. Proporsi PAD dengan jumlah yang tinggi dianggap lebih baik dalam memperkecil probabilitas financial distress, hal ini dikarenakan pemerintah daerah dianggap mampu dalam membentuk pendapatan daerahnya sendiri sehingga ketika dibandingkan dengan total pendapatan yang dimilikinya dapat menunjukkan porsi yang tepat dan tidak begitu kecil. PAD yang tinggi mengindikasikan pemerintah daerah mampu dalam membentuk penghasilan sendiri guna membiayai kegiatan pemerintahannya, sehingga hal tersebut dapat membentuk efektifitas penyelenggaraan kegiatan pemerintahan. Sesuai dengan agency theory pemerintah harus menjalankan tugas semestinya.

Setelah pelaksanaan otonomi daerah sesuai UU No. 12 Tahun 2008 tentang perubahan kedua atas UU No. 32 Tahun 2004 dimana Pendapatan Asli Daerah (PAD) menjadi salah satu instrumen fiskal yang tidak dapat dihindari dalam membangun perekonomian dan kesejahteraan bagi masyarakat daerah. Memperkuat keuagan daerah yang dilakukan dengan PAD dibentuk UU No. 28 tahun 2009 tentang Pajak dan Retribusi Daerah dengan tujuan pemberian wewenang keuangan kepada pemerintah daerah untuk mendorong pendapatan melalui kebijakan dan strategi tertentu yang berdampak pada penguatan ekonomi daerah (Firdausy, 2017). Penjelasan tersebut memperlihatkan bahwa PAD merupakan hal yang penting bagi pemerintah daerah kerena menggambarkan membentuk citra daerah melihat kondisi keuangan melalui kontribusi PAD terhadap total pendapatan, sehingga dapat memberikan kontribusi terhadap pembangunan daerah walaupun saat ini porsi PAD pemerintah daerah pada umumnya masih rendah.

Hipotesis kedelapan dalam penelitian ini yaitu $\left(\mathrm{H}_{3 c}\right)$ total revenue to own revenue ratio mempunyai kemampuan dalam memprediksi financial distress pemerintah daerah. Hasil pengujian hipotesis keempat memiliki nilai signifikansi 0,290 dan koefisien -0,104. Nilai signifikansi yang lebih besar dari 5\% menunjukkan bahwa total revenue to own revenue ratio tidak berpengaruh signifikan terhadap financial distress, sehingga penelitian ini gagal mendukung hipotesis keempat yang menyatakan bahwa total revenue to own revenue ratio berpengaruh signifikan terhadap financial distress. Hasil dari penelitian menandakan bahwa ketergantungan pemerintah daerah kepada pusat dengan mengharapkan transfer belum tentu

Hipotesis kesembilan $\left(\mathrm{H}_{3 \mathrm{~d}}\right.$ ) yaitu depreciation ratio dengan hasil pengujian hipotesis kesembilan ini memiliki nilai signifikan sebesar 0,004 dan koefisien 40.004. Nilai signifikansi tersebut lebih kecil daripada nilai alpha $(0,05)$ atau $(<0,05)$, hal ini berarti H0 ditolak, sehingga pada penelitian ini dapat disimpulkan bahwa Depreciation Ratio berpengaruh signifikan terhadap prediksi financial distress. menunjukkan bahwa depreciation ratio dalam penelitian ini berpengaruh signifikan terhadap financial distress. Keberadaan dari beban depresiasi mempengaruhi jumlah beban operasional yang harus dikeluarkan oleh insansi pemerintah daerah. Keberadaan depresiasi dianggap penting sebagai bentuk penerapan penuh accrual basis karena memberikan prediksi menyangkut dengan layanan publik yang dapat menggambarkan penurunan kemampuan melanjutkan going concern (Heosada, 2017). 
Hipotesis kesepuluh dalam penelitian ini yaitu $\left(\mathrm{H}_{4 a}\right.$ cash flow operation to current liability ratio mempunyai kemampuan dalam memprediksi financial distress pemerintah daerah. Hasil pengujian hipotesis kesepuluh memiliki nilai signifikansi 0,984 dan koefisien 0,000. Nilai signifikansi yang lebih besar dari 5\% menunjukkan bahwa cash flow operation to current liability ratio tidak berpengaruh signifikan terhadap financial distress. Nilai yang ada memperlihatkan angka yang paling tinggi dari pengukuran lainnya dengan angka paling jauh dari 0,05 . Hasil yang didapatkan memberikan kesimpulan bahwa financial distress tidak dipengaruhi secara signifikan oleh arus kas operasi, dimana besar kecilnya nilai arus kas operasi tidak mempengaruhi kondisi financial distress, hal tersebut juga terlihat dari koefisien 0.000 menandakan bahwa rasio ini tidak memiliki pengaruh dalam memberikan nilai relevansi untuk menunjukkan kemampuan dalam memprediksi. Tidak berpengaruhnya arus kas operasi terhadap kondisi financial distress dikarenakan jumlah arus kas yang fluktatif pada perusahaan yang mengalami financial distress maupun perusahaan non financial distress (Nukmaningtyas dan Worokinasih, 2018).

\section{Capital Structure Ratio Dalam Memprediksi Financial Distress}

Capital structure ratio diukur dengan debt to equity ratio nilai signifikansi 0,549 dan koefisien 198.689. Nilai signifikansi yang lebih besar dari 5\% menunjukkan bahwa debt to equity ratio tidak berpengaruh signifikan terhadap financial distress. Hasil yang ada menandakan bahwa besar kecilnya nilai DER tidak mempengaruhi kondisi financial distress, dimana instansi dengan DER yang tinggi belum tentu dikategorikan mengalami financial distress serta begitu juga dengan instansi dengan nilai DER yang lebih rendah belum tentu dikategorikan sebagai perusahaan non financial distress. Hasil olah data yang ditemukan tidak sejalan dengan Sutaryo et al. (2012) yang menemukan bahwa debt to equity ratio terbukti mampu dalam memprediksi status financial distress pemerintah kabupaten kota di Indonesia. Sulitnya untuk melihat pengaruh keberadaan utang juga ditambah dengan pada umummnya kecilnya jumlah utang yang dimiliki oleh pemerintah kabupaten dan kota di Indonesia.

Capital structure ratio longterm liabilities to total asset ratio mendapatkan hasil pengujian hipotesis keempat memiliki nilai signifikansi 0,464 dan koefisien -26.444. Nilai signifikansi yang lebih besar dari 5\% menunjukkan bahwa longterm liabilities to total asset ratio tidak berpengaruh signifikan terhadap financial distress. Hasil yang didapatkan memberikan kesimpulan bahwa financial distress tidak dipengaruhi secara signifikan oleh keberadaan utang jangka panjang instansi pemerintah daerah, dimana besar kecilnya nilai perbandingan antara utang jangka panjang dengan total aset tidak mempengaruhi kondisi financial distress. Hasil ini sejalan dengan Sutaryo et al. (2012) yang menemukan bahwa longterm liabilities to total asset ratio terbukti kurang mampu dalam memprediksi status financial distress pemerintah daerah, terutama hasil observasi pada laporan keuangan pemerintah daerah memperlihatkan bahwa utang jangka panjang yang dimiliki oleh pemerintah daerah jumlahnya kecil bahkan jika diamati pada seluruh laporan keuangan hanya sedikit pemda yang memiliki untang jangka panjang.

Pengukuran menggunakan debt to total asset ratio memiliki nilai signifikansi 0,586 dan koefisien 206.350. Nilai signifikansi yang lebih besar dari 5\% menunjukkan bahwa debt to total asset ratio tidak berpengaruh signifikan terhadap financial distress penelitian sejalan dengan Sutaryo et al. (2012) yang menemukan bahwa debt to total asset ratio tidak terbukti mampu untuk digunakan dalam memprediksi status financial distress, serta hal ini sejalan dengan Marlin (2017) yang menyatakan bahwa debt to total asset ratio belum tentu menandakan instansi memiliki beban yang besar sehingga mengarah pada kesulitan keuangan. Hal lainnya sesuai 
pengamatan dari laporan keuangan pemerintah daerah yang menyebabkan debt to total asset ratio menjadi tidak relevan dalam memprediksi status financial distress dikarenakan nilai besaran utang atau pinjaman yang dilakukan oleh pemerintah daerah cukup rendah sehingga tidak signifikan dalam ketika dilakukan perhitungan.

Pengukuran menggunakan debt to revenue ratio memiliki nilai signifikansi 0,126 dan koefisien 28.510. Nilai signifikansi yang lebih besar dari 5\% menunjukkan bahwa debt to revenue ratio tidak berpengaruh signifikan terhadap financial distress. Hasil ini sejalan dengan temuan Sutaryo et al. (2012) yang menemukan bahwa debt to revenue ratio dianggap tidak mampu dalam memprediksi status financial distress pemerintah kabupaten dan kota di Indonesia. Penelitian ini juga sejalan dengan penelitian Cohen (2008) yang mengatakan bahwa debt to revenue ratio tidak atau kurang berpengaruh pada kinerja pemerintah di Kota Greek, Yunani dikarenakan rasio ini lebih cendrung dipengaruhi oleh jumlah penduduk dan perkapita sehingga tidak langsung berpengaruh pada financial distress.

\section{KESIMPULAN DAN SARAN \\ Kesimpulan}

Berdasarkan hasil pengolahan dan analisis data yang telah peneliti lakukan sebelumnya, maka dapat ditarik kesimpulan sebagai berikut:

1. Profitability ratio yang diukur menggunakan profit margin ratio nilainya berpengaruh signifikan terhadap financial distress pemerintah daerah kabupaten dan kota di Indonesia dikarenakan pendapatan yang ada digunakan sebagai bentuk investasi untuk memaksimalkan pendapatan dikemudian hari sehingga dapat membentuk efektifitas (Halim, 2008), sedangkan return on asset dan return on equity ratio menghasilkan nilai tidak berpengaruh signifikan terhadap financial distress dikarenakan ketidaksesuaian hasil yang didapatkan dikarenakan surplus pemda tidak berasal dari efisiensi, akan tetapi surplus yang ada tersebut berasal dari alokasi anggaran kegiatan yang tidak direalisasikan (Wibowo dan Sumekto, 2013) .

2. Liquidity ratio yang diukur menggunakan current ratio dan working capital ratio menghasilkan nilai tidak berpengaruh signifikan terhadap financial distress pemerintah daerah kabupaten dan kota di Indonesia dikarenakan likuiditas tinggi tidak memberi jaminan lepas financial distress dikarenakan seringkali instansi yang liquid mengalami financial distress (Tukan, 2017).

3. Performance ratio yang diukur menggunakan operating revenue to operating expenses menghasilkan nilai tidak berpengaruh signifikan terhadap financial distress pemerintah daerah kabupaten dan kota di Indonesia kemampuan pemerintah daerah dalam memenuhi kebutuhan beban operasi tidak memberikan jaminan akan terbebasnya pemerintah daerah tersebut dari potensi financial distress sedangkan ukuran dengan operating revenue to total revenue berpengaruh signifikan terhadap financial distress dikarenakan dimana Pendapatan Asli Daerah (PAD) menjadi salah satu instrumen fiskal membangun perekonomian dan kesejahteraan masyarakat (Firdausy, 2017) depreciation ratio menghasilkan berpengaruh signifikan terhadap financial distress dengan layanan publik yang dapat menggambarkan penurunan kemampuan melanjutkan going concern (Heosada, 2017), cash flow operation to current liability tidak berpengaruh signifikan terhadap financial distress karena jumlah arus kas yang fluktatif pada perusahaan yang mengalami financial distress maupun perusahaan non financial distress (Nukmaningtyas dan Worokinasih, 2018).

4. Capital structure ratio yang diukur menggunakan debt to equity ratio tidak berpengaruh signifikan terhadap financial distress pemerintah daerah kabupaten dan kota di Indonesia 
karena sulitnya untuk melihat pengaruh keberadaan utang serta kecilnya porsi hutang pemerintah daerah, longterm debt to total asset tidak berpengaruh signifikan terhadap financial distress karena sulit melihat pengaruh hutang jangka panjang, debt to total asset ratio tidak berpengaruh signifikan terhadap financial distress dikarenakan belum tentu menandakan instansi memiliki beban yang besar sehingga mengarah pada kesulitan keuangan (Marlin, 2017) dan debt to revenue ratio menghasilkan nilai tidak berpengaruh signifikan terhadap financial distress pemerintah daerah karena debt to revenue lebih cendrung dipengaruhi oleh jumlah penduduk dan perkapita sehingga tidak langsung berpengaruh pada financial distress (Cohen, 2008).

\section{Keterbatasan}

Penelitian yang dilakukan telah dirancang dengan sebaik-baiknya, namun peneliti menyadari bahwa penelitian ini mempunyai beberapa keterbatasan. Keterbatasan dalam penelitian ini adalah:

1. Ukuran yang digunakan sebagai indikator untuk mengukur dan mengelompokkan variabel dependen hanya menggunakan ukuran rasio belanja terhadap total belanja secara keseluruhan berdasarkan peraturan pemerintah yang dianggap belum dapat menggambarkan secara keseluruhan financial distress yang terdapat dalam sektor publik.

2. Penelitian ini hanya menggunakan indikator keuangan sebagai variabel independen dalam penelitian tanpa variabel non keuangan.

3. Sumber referensi yang dijadikan panduan oleh peneliti dalam melaksanakan dan mengembangkan penelitian terkait relevansi informasi akuntansi dalam memprediksi status financial distress pemerintah daerah jumlahnya masih sangat terbatas.

\section{Saran}

Berdasarkan pembahasan yang terdapat dalam penelitian ini, maka saran peneliti adalah sebagai berikut:

1. Untuk Pemerintah Pusat

Melakukan upaya yang dapat mendorong pemerintah daerah untuk meningkatkan pembangunan infrastruktur yang dapat digunakan untuk pelayanan publik.

2. Untuk Pemerintah Daerah Kabupaten dan Kota di Indonesia

Berupaya dengan mengalokasikan belanja daerah dengan tepat salah satunya dengan mengurangi belanja pegawai dan mengalokasikannya ke belanja modal. Hal ini dilakukan untuk mendorong pembangunan infrastruktur dalam rangka pelayanan kepada publik yang lebih baik.

3. Untuk Penelitian Berikutnya

a) Menggunakan indikator keuangan dan non keuangan sebagai variabel independen. Beberapa contoh indikator non keuangan tersebut adalah good governance, kondisi wilayah, jumlah penduduk, pemekaran wilayah dan umur daerah.

b) Menggunakan indikator lain yang dapat menggambarkan kondisi financial distress pemerintah daerah secara luas. 


\section{DAFTAR PUSTAKA}

Bastian, I. (2005). Akuntansi Sektor Publik. Yogyakarta: Erlangga.

Cohen, S. (2008). Identifying The Moderator Factors of Financial Performnce in Greek Municipalities. Financial Accountability \& Management 24(3).

Cohen, S. et al. (2012). Assessing Financial Distress Where Bankruptcy Is Not An Option: An Alternative Approach For Local Municipalities. European Journal of Operational Research (218): 270-279.

Curwin, J. and Slater, R. (2008). Quantitative Methods for Business Decisions. London: Thomson Business Press.

Dwijayanti, S. P. (2010). Penyebab, Dampak, dan Prediksi dari Financial Distress serta Solusi untuk Mengatasi Financial Distress. Jurnal Akuntansi Kontemporer. Vol 2 (2): 191-205.

Erlina, et al. (2015). Akuntansi Keuangan Daerah Berbasis Akrual Berdasarkan PP No. 72 Tahun 2010 dan Permendagri No.64 Tahun 2013. Jakarta: Salemba Empat.

Firdausy, C. M. (2017). Kebijakan dan Strategi Peningkatan Pendapatan Asli Daerah dalam Pembangunan Nasional. Jakarta: Yayasan Obor Indonesia.

Halim, A. (2008). Analisis Investasi (Belanja Modal) Sektor Publik- Pemerintah Daerah. Yogyakarta: UPP Sekolah Tinggi Ilmu Manajemen YKPN.

Hammam, M. (2017). Perjalanan Akuntansi Aset Tetap pada Pemerintah Daerah Di Indonesia dan Capital Charging Sebagai Wacana Pengembangannya. Jurnal Tata Kelola \& Akuntabilitas Keuangan Negara, 3 (1): 21 - 31.

Hosmer, D. W. \& Lemeshow, S. (2000). Applied Logistic Regression. Canada: John Willey \& Sons, Inc.

http://www.bpk.go.id

https://seknasfitra.org

Jensen, M. C. \& Meckling, W. H. (1976). Theory of the Firm: Managerial Behaviour, Agency Costs and Ownership Structure. Journal of Financial Economics, 3 (4): 305-360.

Jones, S. dan Walker, R. G. (2007). Explanators of Local Goverment Distress. ABACUS. 43(3): 396-418

Kasmir. (2014). Analisis Laporan Keuangan. Edisi Satu. Cetakan Ketujuh. Jakarta: PT Raja Grafindo Persada.

Kholidah, et al. (2016). Analisis Rasio Keuangan Dalam Memprediksi Financial Distress Pada Perusahaan Sektor Industri Dasar Dan Kimia Yang Terdaftar di Bei Tahun 2011-2015. Jurnal Bisnis dan Manajemen, 10 (3): 279 - 291.

Mahmudi. (2010). Analisis Laporan Keuangan Pemerintah Daerah. Edisi 2. Yogyakarta: UPP STIM YKPN.

Marlin, Y. (2017). Pengaruh Current Ratio, Debt to Total Asset Ratio dan Total Assets Turn Over terhadap Kondisi Financial Distress. eJournal Administrasi Bisnis, 5 (4):855-866.

Maulida, I. et al. (2018). Analisis Rasio Keuangan Untuk Memprediksi Financial Distress Pada Perusahaan Manufaktur Yang Terdaftar Di Bursa Efek Indonesia 2014-2016. JIABI 2 (1).

Nukmaningtiyas dan Worokinasih. (2018). Penggunaan Rasio Profitabilitas, Likuiditas, Leverage dan Arus Kas untuk Memprediksi Financial Distres. Jurnal Administrasi Bisnis 61 (2).

Peraturan Pemerintah Republik Indonesia Nomor: 24 Tahun 2005. Tentang Standar Akuntansi Pemerintahan.

Peraturan Pemerintah Republik Indonesia Nomor: 71 Tahun 2010. Tentang Standar Akuntansi Pemerintahan. 
Peraturan Presiden Republik Indonesia Nomor: 2 Tahun 2015. Tentang Rencana Pembangunan Jangka Menengah Nasional Tahun 2015-2019.

Peraturan Presiden Republik Indonesia Nomor: 5 Tahun 2010. Tentang Rencana Pembangunan Jangka Menengah Nasional Tahun 2010-2014.

Plummer, et al. 2007. GASB No.34's Governmental Financial Reporting Model: Evidence on Its Information Relevance. The Accounting Review, 82 (1): 205-240.

Restianti dan Agustina. (2018). The Effect of Financial Ratios on Financial Distress Conditions In Sub Industrial Sector Company. Accounting Analysis Journal 7 (1): 25-33

Ritongga, I. T. et al. (2012). Assessing Financial Condition of Local Government in Indonesia: an Exploration. Public and Municipal Finance, 1: 37-50.

Riyanto, B. (2008). Dasar-Dasar Pembelanjaan Perusahaan. Yogyakarta: GPFE.

Sartika, D. (2016). Analisis Prediksi Financial Distress Pemerintah Daerah Kabupaten/Kota di Indonesia Periode 2011-2013. Naskah Publikasi. Surakarta, Universitas Muhammadiyah Surakarta.

Sirait. (2016). Analisis Rasio Keuangan untuk Memprediksi Kondisi Financial Distress pada Perusahaan Manufaktur yang Terdaftar di Bursa Efek Indonesia. Repositori Institusi USU.

Subramanyam, K.R. \& Wild, J. J. (2010). Analisis Laporan Keuangan. Jakarta: Salemba Empat.

Surepno. (2013). Pengaruh Return on Equity (ROE), Ukuran (Size), dan Kemakmuran (Wealth) Pemerintah Daerah Terhadap Kinerja Keuangan Pemerintah Daerah di Indonesia. Skripsi. Tidak Diterbitkan. Fakultas Ekonomi. Universitas Negeri Semarang.

Sutaryo, B., dan Doddy, S. (2010). Nilai Relevan Informasi Laporan Keuangan Terkait Financial Distress Pemerintah Daerah. Simposium Nasional Akuntansi XIII. Purwokerto, 13-14 Oktober.

Sutaryo, et al. (2012). Relevansi Informasi Laporan Keuangan Cash Modified Basis: Kemampuan Rasio Keuangan dalam Memprediksi Status Financial Distress Pemerintah Daerah di Indonesia. Jurnal dan Prosiding SNA-Simposium Nasional Akuntansi.

Turaboglu, et al. 2017. Finansal Basarizlik ve Sermaye Yapisi Kararlari: BIST 100 Endeksindeki Firmalar Uzerine Bir Uygulama. Business and Economics Research Journal, 8 (2): $247-$ 258.

Wibowo dan Sumekto. (2013). The Relevance of Accounting Information and Financial Distress of Local Government in East Java. The Indonesian Accounting Review, 3 (1): 43-52.

Yanti, R. D. (2018). Kemampuan Rasio Keuangan dalam Memprediksi Status Financial Distress Pemerintah Daerah Kabupaten dan Kota di Provinsi Sumatera Barat Periode 2012-2016, Jurnal UNP. 